\title{
ANIMASI PANDUAN PEMBUATAN SERTA PENGGUNAAN HAND SANITIZER DAN DISINFEKTAN YANG AMAN DAN EFEKTIF DI MASA PANDEMI COVID-19
}

\author{
Annisa Auliya ${ }^{1}$, Aulia Siti Pathoni ${ }^{1}$, Devi Aliefiyardi Aulia Widowati ${ }^{1}$, Nita Aresanti ${ }^{1}$, \\ Rina Agustina ${ }^{2}$, Setia Budi ${ }^{1}$, Muktiningsih Nurjayadi ${ }^{3}$, Ucu Cahyana ${ }^{3}$ \\ ${ }^{1}$ Program Studi Kimia, Fakultas Matematika dan Ilmu Pengetahuan Alam, \\ Universitas Negeri Jakarta \\ ${ }^{2}$ Program Studi Teknologi Pendidikan, Fakultas Ilmu Pendidikan, Universitas Negeri \\ Jakarta \\ ${ }^{3}$ Program Studi Pendidikan Kimia, Fakultas Matematika dan Ilmu Pengetahuan Alam, \\ Universitas Negeri Jakarta \\ E-mail: annisaauliya29@gmail.com
}

\begin{abstract}
The COVID-19 pandemic occurred in many parts of the world has disrupted many aspects of life. One precaution to protect ourselves from this virus is cleaning our hands by using hand sanitizers and cleaning surfaces that are frequntly touched by using disinfectants. Therefore, there is tremendous need of this chemical substance in this pandemic era. This fact enforces people to make this chemical at home.. This homemade manufacture and use of sanitizers and disinfectants must be in accordance with the regulations, so that they don't cause any harmful effects for the body. This program is carried out with the aim of providing education to the community, especially residents of Duren Sawit Village. The media used in this program are Instagram and YouTube, and the materials were delivered in form of videos. Videos were uploaded to Instagram and YouTube on $2-23$ June 2020. After that, a questionnaire was filled on 23 June - 1 July 2020. From the questionnaire data, it can be shown that the respondents have benefited from the video generally. The benefits obtained by the community were dealing with the functions and active ingredients contained in hand sanitizers and disinfectants; method of producing hand sanitizers and disinfectants; the importance of providing hand sanitizers and disinfectants at home; caution in using hand sanitizers and disinfectants; as well as the impact if there is a misuse of hand sanitizer or disinfectant. Through this program, it is expected that the community will be able to make and use sanitizers and disinfectants safely and effectively to achieve a healthier Indonesia.
\end{abstract}

Keywords: COVID-19, disinfectant, education, hand sanitizer

\begin{abstract}
Abstrak
Pandemi COVID-19 yang terjadi di berbagai belahan dunia mengakibatkan banyak aspek kehidupan terganggu. Salah satu tindakan pencegahan untuk melindungi diri kita dari virus ini adalah dengan membersihkan tangan menggunakan hand sanitizer dan membersihkan benda-benda yang sering tersentuh dengan disinfektan. Oleh karena itu, di masa pandemi kebutuhan bahan kimia tersebut meningkat tajam dan mendorong masyarakat untuk membuatnya sendiri di rumah. Pembuatan mandiri serta penggunaan hand sanitizer dan disinfektan ini harus sesuai aturan sehingga tidak menimbulkan efek yang tidak baik bagi tubuh. Program ini dilakukan dengan tujuan memberi edukasi kepada masyarakat, khususnya warga Kelurahan Duren Sawit, Kota Jakarta Timur. Materi disampaikan dengan video animasi melalui media Instagram dan YouTube. Video diunggah ke Instagram dan YouTube pada 2 - 23 Juni 2020. Setelah itu, dilakukan pengisian angket pada 23 Juni - 1 Juli 2020. Dari hasil angket, secara umum responden menyatakan sudah mendapatkan manfaat dari video yang dibagikan. Manfaat yang diperoleh masyarakat
\end{abstract}


berupa fungsi, dan bahan aktif yang terkandung dalam hand sanitizer dan disinfektan; cara membuat hand sanitizer dan disinfektan; pentingnya penyediaan hand sanitizer dan disinfektan di rumah; beberapa peringatan dalam menggunakan hand sanitizer dan disinfektan; serta dampak yang ditimbulkan jika ada kesalahan dalam menggunakan hand sanitizer atau disinfektan. Melalui program ini diharapkan masyarakat mampu membuat serta menggunakan sanitizer dan disinfektan dengan aman dan efektif untuk mencapai Indonesia yang lebih sehat.

Kata kunci: COVID-19, disinfektan, edukasi, hand sanitizer

\section{PENDAHULUAN}

\section{Pandemi}

COVID-19 mempengaruhi segala aspek kehidupan, hingga akhirnya muncul kebijakan new normal yang mengimbau masyarakat untuk sering mencuci tangan dengan sabun, menjaga jarak, dan memakai masker. Untuk mencegah penularan COVID-19, diberlakukan juga kebijakan pembelajaran jarak jauh (PJJ) dan pembatasan sosial berskala besar (PSBB). Penularan COVID-19 dapat melalui droplet, batuk, tangan atau permukaan yang terkontaminasi. Namun, penularan dari satu orang ke orang lain dapat dikurangi dengan sering mencuci tangan menggunakan sabun dan air atau disinfektan berbasis alkohol seperti yang direkomendasikan WHO (Pradhan, Biswasroy, Kumar, Ghosh, \& Rath, 2020). Namun, mencuci tangan dengan sabun tidak selalu mudah dilakukan. Penggunaan hand sanitizer dapat menjadi pilihan saat mencuci tangan sulit dilakukan. Penggunaan disinfektan untuk membersihkan gedung-gedung dan permukaan benda mati yang sering tersentuh juga semakin marak dilakukan selama pandemi COVID-19. Bahkan, WHO juga mengeluarkan formula agar masyarakat mampu membuat hand sanitizer dan disinfektan secara mandiri. Namun, pembuatan hand sanitizer dan disinfektan secara mandiri memerlukan panduan ilmiah agar produk yang dihasilkan tidak menimbulkan efek yang tidak baik bagi tubuh.

Adanya kebijakan work from home selama pandemi COVID-19 turut meningkatkan jumlah pengguna internet. Jumlah pengguna internet Indonesia periode 2019 hingga kuartal II 2020 mengalami kenaikan menjadi 73,7 persen dari populasi atau setara 196,7 juta pengguna. Menurut Badan Pusat Statistik, pengguna internet hampir tembus 200 juta orang dari populasi RI yang 266,9 juta jiwa. Selama pandemi COVID-19, mayoritas pengguna mengakses internet lebih dari 8 jam dalam sehari. Konten media yang paling banyak diakses selama pandemi COVID-19 adalah konten pendidikan dan laman sekolah. Hal ini mungkin terjadi karena adanya pembelajaran jarak jauh. Selan itu, situs belanja online dan media sosial seperti Facebook, Instagram, Twitter, dan YouTube juga sering diakses oleh masyarakat (APJII, 2020).

Berdasarkan hal tersebut, maka Universitas Negeri Jakarta turut berinovasi untuk menyelenggarakan kegiatan yang mampu memberikan manfaat untuk masyarakat pada situasi pandemi, salah satunya dengan melaksanakan Kuliah Kerja Nyata 
(KKN) Edukasi COVID-19. KKN ini bertujuan untuk memberikan informasi mengenai pembuatan serta penggunaan hand sanitizer dan disinfektan yang aman dan efektif di masa pandemi COVID-19 dengan menggunakan video animasi. Penggunaan animasi dimaksudkan agar materi yang disampaikan lebih menarik dan mudah dipahami oleh masyarakat.

\section{TINJAUAN LITERATUR}

\subsection{Media Audio Visual}

Media audio visual diartikan sebagai sarana yang dapat memberikan pengalaman visual kepada peserta didik, dengan tujuan untuk mendorong motivasi belajar, memperjelas, dan memudahkan pemahaman konsep yang abstrak serta mempertinggi daya serap belajar. Penyampaian pesan melalui audio visual bercirikan pemakaian perangkat keras, seperti mesin proyektor film, tape recorder, dan proyektor visual yang lebar yang penyerapannya melalui pandangan dan pendengaran. Media audio visual diklasifikasikan menjadi dua macam, yaitu audio visual diam dan audio visual gerak. Audio visual diam yaitu media yang dapat menampilkan unsur suara dan gambar diam seperti film rangkai suara. Audio visual gerak yaitu media yang dapat menampilkan unsur suara dan gambar yang bergerak seperti film suara, pita video, film televisi, dan video animasi.

Pada pelaksanaan KKN Edukasi COVID-19 ini, video animasi digunakan sebagai media penyampai pesan. Media animasi dapat disebut juga sebagai media film. Media animasi merupakan pergerakan sebuah objek atau gambar sehingga dapat berubah posisi, bentuk, dan warna serta memiliki suara (C. Kustandi, D. Darmawan, 2020). Penggunaan video animasi pada kegiatan ini bertujuan untuk menarik perhatian penonton sehingga dapat memberikan pemahaman yang lebih cepat.

\subsection{Hand Sanitizer}

Hand sanitizer, atau disebut juga antiseptik tangan, handrub, atau hand $r u b$, merupakan bahan yang dioleskan pada tangan untuk menghilangkan organisme patogen penyebab penyakit. Hand sanitizer biasanya berbentuk busa, gel, atau cairan. Penggunaannya dianjurkan jika sabun dan air tak tersedia untuk mencuci tangan (Rogers, 2020). Penularan COVID-19 antar manusia dapat dikurangi dengan sering mencuci tangan dengan sabun dan air atau dengan disinfektan berbasis alkohol seperti yang direkomendasikan oleh WHO. Alkohol digunakan sebagai agen disinfektan/biosidal yang umum sejak zaman kuno. Sifat disinfektan/biosidal alkohol tergantung pada konsentrasi dan jenis alkohol yang digunakan. Aktivitas antivirus dari alkohol yang berbeda dapat ditentukan dengan mengevaluasi indeks infektivitas virus (nilai $\log _{10}$ ). Infektivitas virus adalah kemampuan virus untuk menembus sel inang dan menggunakannya untuk produksi partikel virus lebih lanjut (Sanjua, 2018). Berdasarkan nilai indeks infektivitas virus, formulasi WHO-I yang terdiri dari etanol $(85 \%)$, gliserol $(0,725 \%)$ dan hidrogen peroksida $(0,125 \%)$ menunjukkan aktivitas antivirus yang 
lebih baik daripada formulasi WHO-II yang memiliki komposisi isopropanol $(75 \%)$, gliserol $(0,725 \%)$ dan hidrogen peroksida $(0,125 \%)$ (Friesland et al., 2017).

Aktivitas biosidal alkohol dimediasi melalui koagulasi protein permukaan mikroba. Secara eksperimen, teramati bahwa konsentrasi alkohol di bawah 50\% menunjukkan aktivitas biosidal (sifat bakterisidal, virusidal, atau fungisidal) yang rendah. Konsentrasi alkohol lebih dari 90\% menggumpalkan protein mikroba secara instan. Akibatnya, protein yang terkoagulasi bertindak sebagai perisai untuk protein mikroba, sehingga membutuhkan waktu kontak yang lebih lama untuk respon biosidal. Sebagai contoh, 50\% isopropil alkohol membunuh Staphylococcus aureus dalam waktu kurang dari 10 detik, sementara $90 \%$ isopropil memerlukan waktu kontak lebih dari dua jam sehingga tidak efektif. Selain itu, perubahan panjang rantai aktivitas virusidal alkohol alifatik bervariasi. Sebagai contoh, aktivitas virusidal dari alkohol alifatik yang rendah meningkat dalam seri metil < etil < propil < butil < amil untuk virus lipofil, sedangkan urutan terbalik umumnya berlaku untuk virus hidrofilik seperti picornavirus (Springthorpe \& Sattar, 2009). Berdasarkan literatur, hand sanitizer yang mengandung 60 - 95\% alkohol menunjukkan aktivitas bakterisidal optimum. Alkohol ini mampu melarutkan membran lipid dan mendenaturasikan protein pada mikroba (Lee et al., 2020).

\begin{tabular}{llr}
\multicolumn{1}{c}{ Beberapa } & hal yang & perlu \\
dipertimbangkan & saat & sering \\
menggunakan & pembersih & tangan
\end{tabular}
berbasis alkohol antara lain minyak yang disekresikan dari kelenjar sebaceous pada permukaan kulit terdiri dari asam lemak bebas, khususnya asam laurat dan asam sapienat, yang memiliki aktivitas antivirus (Wertz, 2018); sering menggunakan hand-sanitizer berbahan dasar alkohol dapat menghilangkan minyak dari permukaan kulit sehingga menyebabkan kulit kering; kulit yang mengalami dehidrasi/kering ditandai dengan kutikula yang pecah-pecah, sehingga mempermudah patogen untuk menembus lapisan kulit yang lebih dalam dan mempermudah infeksi kuman. Selain itu, potensi bahaya kebakaran dari sanitizer berbasis alkohol juga merupakan faktor risiko yang tidak bisa dihindari (Pradhan et al., 2020).

\subsection{Disinfektan}

Disinfektan merupakan bahan
yang dapat menghancurkan,
pertumbuhan mikroorganisme patogen pada benda mati. Produk disinfektan dibagi menjadi dua jenis: penggunaan untuk rumah sakit dan untuk umum. Disinfektan untuk rumah sakit berguna sebagai pengontrol infeksi dan pembersih instrumen medis, lantai, dinding, tempat tidur, dan permukaan benda lainnya. Sementara disinfektan umum digunakan untuk keperluan rumah tangga dan penjernih air/kolam renang (Extension, 2011). Permukaan suatu benda adalah tempat paling rawan untuk transmisi penularan infeksi COVID-19 dari satu orang ke orang 
yang lain. Waktu kehadiran virus bisa bervariasi dari 1-9 hari, dimana tergantung pada sifat permukaan, $\mathrm{pH}$, suhu dan kelembaban relatif dari lingkungan di sekitarnya (Gunter, 2020).

Umumnya senyawa amonium kuaterner, hidrogen peroksida, alkohol (etanol, isopropil alkohol, fenol), aldehida, asam hipoklorit, asam oktanoat, asam sitrat yang terkonjugasi dengan ion perak, natrium hipoklorit, natrium bikarbonat, adalah bahan utama yang memiliki aktivitas virusidal. Etanol (7895\%) dan isopropanol (70-100\%) digunakan sebagai disinfektan yang efektif karena menunjukkan aktivitas virusidal yang kuat dengan efek toksik yang rendah pada kulit manusia. Semua virus yang diselimuti lipid dinonaktifkan dalam waktu 2 menit. Mekanisme kerja disinfektan berbasis alkohol kurang dipahami, namun pengendapan protein permukaan mungkin dapat menjadi salah satu kunci mekanisme yang bertanggung jawab untuk aktivitas virusidal. Selain itu, senyawa amonium kuaterner juga paling banyak diintegrasikan ke dalam formulasi desinfektan permukaan.

Senyawa amonium kuarterner memiliki nitrogen pusat sebagai bagian kationik yang dikelilingi oleh anion halogen bermuatan negatif. Senyawa amonium kuarterner diklasifikasikan menurut sifat gugus alkil (gugus R) yang meliputi jumlah atom nitrogen, percabangan rantai karbon, dan adanya gugus aromatik. Variasi dalam panjang rantai, ukuran inti, dan kebasaan kompleks menentukan kemampuan antimikroba. Misalnya, peningkatan panjang rantai dari $\mathrm{C}_{12}-\mathrm{C}_{16}$ menunjukkan aktivitas antimikroba terbesar. Zat ini merupakan gugus pengaktif membran karena berinteraksi langsung dengan membran sitoplasma bakteri dan ragi (Wieczorek, Dobrowolski, \& Staszak, 2017). Kehadiran ekor nonpolar panjang membuatnya efektif melawan virus yang mengandung lipid, seperti COVID-19. Panjang rantai hidrokarbon berperan sebagai peningkat permeabilitas yang mempengaruhi sifat aktif permukaan, sedangkan bagian kationik berikatan dengan asam nukleat yang bermuatan negatif dan terkondensasi di dalam kapsid sehingga menyebabkan aktivitas virusidal (Requiã, Car, Hoyer, \& Ri, 2020). Kelompok disinfektan lainnya yang termasuk senyawa halogen yaitu asam hipoklorit, ion hipoklorit.

\section{METODE PELAKSANAAN}

3.1 Tempat dan Waktu Pelaksanaan KKN dilaksanakan di rumah masing-masing karena pandemi COVID-19 masih melanda Indonesia. Sasaran dalam KKN Edukasi COVID-19 ini adalah masyarakat Kelurahan Pondok Bambu, Kecamatan Duren Sawit, Kota Jakarta Timur.

\subsection{Proses Pembuatan Video}

Aplikasi yang digunakan selama pembuatan video, antara lain: Microsoft Word, Microsoft PowerPoint, Autodesk Sketchbook, Adobe After Effects, dan Adobe Premiere. Pembuatan video dimulai dengan perekaman narasi. Narasi yang direkam merupakan penjabaran secara audio dari materi yang 
sebelumnya telah dibuat. Selain itu, dibuat juga maskot beserta gambargambar pendukung seperti hand sanitizer, disinfektan, virus, dan lainlain. Beberapa gambar juga ada yang diunduh dari flaticon.com.

Video kemudian dibuat dengan Adobe After Effects, Adobe Premiere, dan Microsoft PowerPoint. Terdapat beberapa video yang digunakan sebagai penambah ilustrasi dari narasi yang diunduh dari platform YouTube dan telah dimuat dalam daftar referensi video. Adanya penambahan suara latar belakang yang digunakan bertujuan untuk menghidupkan video yang didapat dari lagu tidak berbayar dan bebas royalti yang ada di internet.

\subsection{Penyebaran Video dan Angket}

Video diunggah di YouTube serta Instagram, seperti yang ditunjukkan pada Gambar 1 dan Gambar 2, kemudian link videonya disebar kepada masyarakat Kelurahan Duren Sawit. Setelah menonton video, masyarakat diminta untuk mengisi angket untuk meninjau pemahaman masyarakat terhadap video yang sudah disebar.

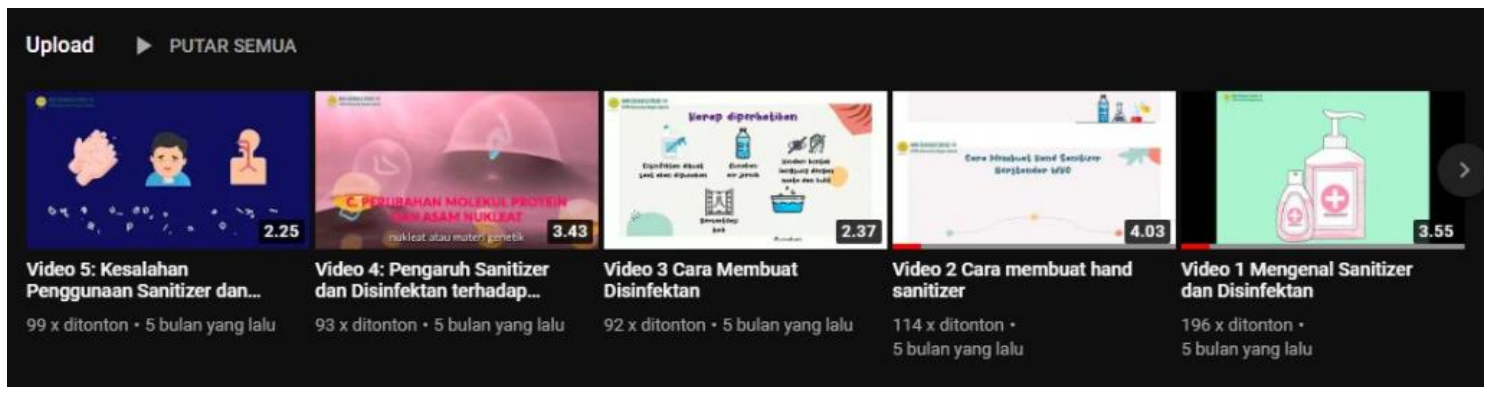

Gambar 1. Video animasi yang disebarluaskan melalui YouTube

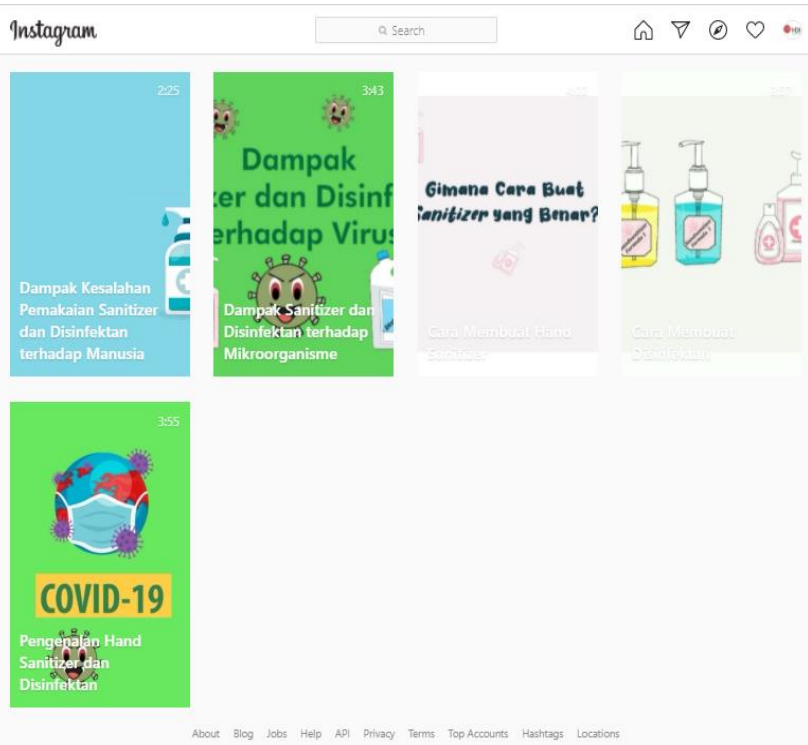

Gambar 2. Video animasi yang disebarluaskan melalui Instagram 


\section{HASIL DAN PEMBAHASAN}

4.1 Hasil Pengunggahan Video dan Penyebaran Angket

Video yang diunggah ke YouTube dan Instagram di-share melalui pesan broadcast WhatsApp agar masyarakat mengetahui bahwa konten KKN Edukasi COVID-19 sudah siap ditonton. Setelah menonton video, masyarakat diminta mengisi angket. Dari angket yang disebar secara online, ada 106 responden yang memberikan tanggapan. Rentang usia responden berkisar antara 17-78 tahun. Responden wanita sebanyak $67,3 \%$ dan responden laki-laki sebanyak 32,7\%. Pekerjaan dari responden bervariasi, diantaranya ialah bidan, perawat, guru, karyawan swasta, wirausaha, pelajar, ibu rumah tangga, dan lainnya. Tanggapan masyarakat terhadap pernyataan terkait Video KKN Edukasi COVID-19 dinyatakan dalam grafik berikut:

- Pernyataan no. 1: Video KKN Edukasi COVID-19 membuat saya memahami fungsi penggunaan hand sanitizer dan disinfektan yang benar

\section{Jumlah Responden}

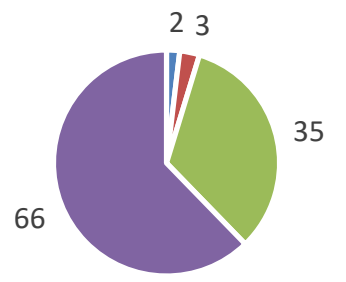

- Sangat Tidak Setuju

- Tidak Setuju

Setuju

- Sangat Setuju

Gambar 3. Tanggapan responden dari pernyataan no. 1

- Pernyataan no. 2: Video KKN

Edukasi COVID-19 membuat saya terkandung dalam hand sanitizer dan disinfektan

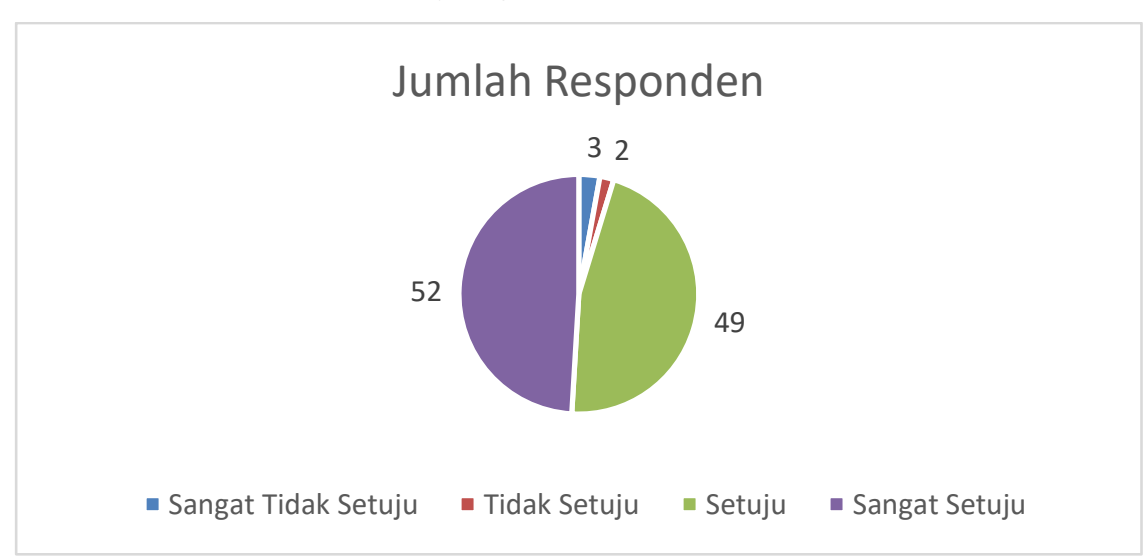

Gambar 4. Tanggapan responden dari pernyataan no. 2 
- Pernyataan no. 3: Video KKN Edukasi COVID-19 membuat saya menyadari perbedaan antara hand sanitizer dan disinfektan

\section{Jumlah Responden}

Gambar 5. Tanggapan responden dari pernyataan no. 3

- Pernyataan no. 4: Video KKN

Edukasi COVID-19 membuat saya memahami cara membuat hand sanitizer sesuai standar WHO

\section{Jumlah Responden}

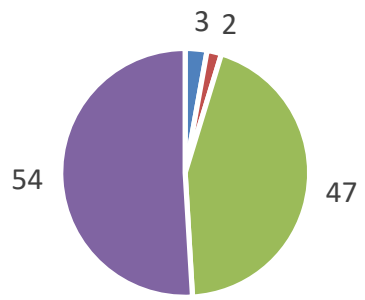

- Sangat Tidak Setuju

- Tidak Setuju

I Setuju

- Sangat Setuju

Gambar 6. Tanggapan responden dari pernyataan no. 4

- Pernyataan no. 5: Video KKN memahami cara membuat Edukasi COVID-19 membuat saya disinfektan sesuai standar WHO

\section{Jumlah Responden}

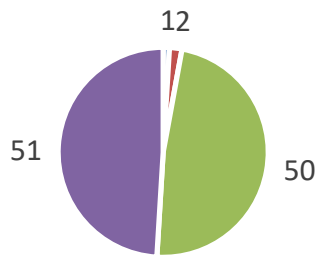

- Sangat Tidak Setuju = Tidak Setuju - Setuju - Sangat Setuju

Gambar 7. Tanggapan responden dari pernyataan no. 5

Sarwahita : Jurnal Pengabdian Kepada Masyarakat Vol. 18 No. 1 Tahun 2021 | 43 
- Pernyataan no. 6: Video KKN hand sanitizer dan disinfektan di Edukasi COVID-19 membuat saya rumah menyadari perlunya pernyediaan

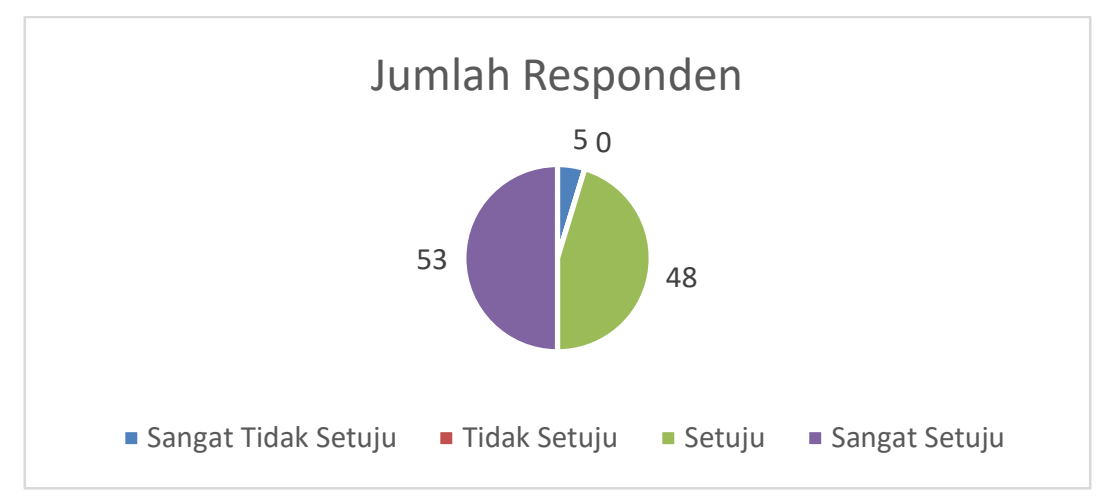

Gambar 8. Tanggapan responden dari pernyataan no. 6

- Pernyataan no. 7: Video KKN

Edukasi COVID-19 membuat saya menyadari dampak yang ditimbulkan jika ada kesalahan dalam menggunakan hand sanitizer atau disinfektan

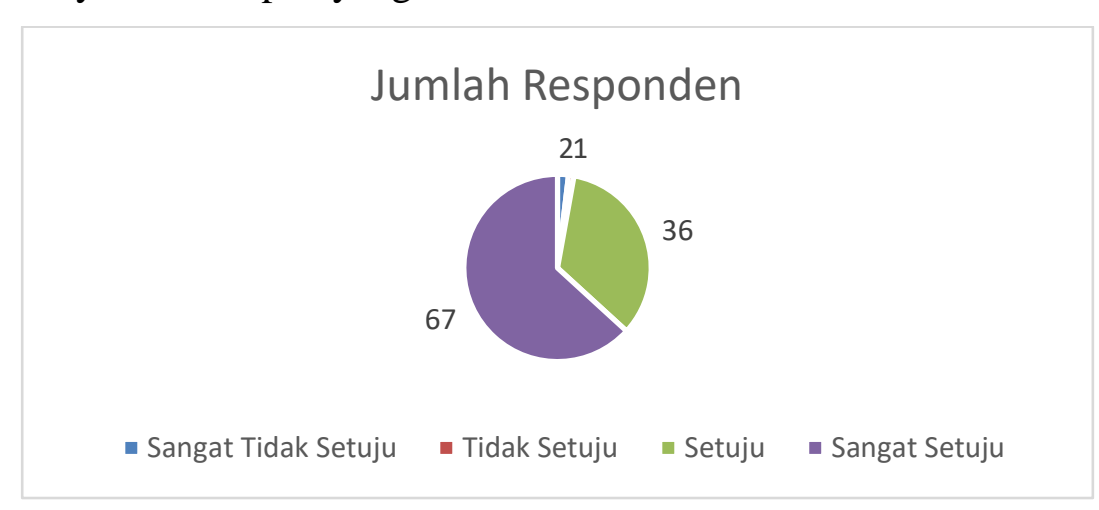

Gambar 9. Tanggapan responden dari pernyataan no. 7

- Pernyataan no. 8: Video KKN Edukasi COVID-19 membuat saya berhati-hati dalam menggunakan disinfektan

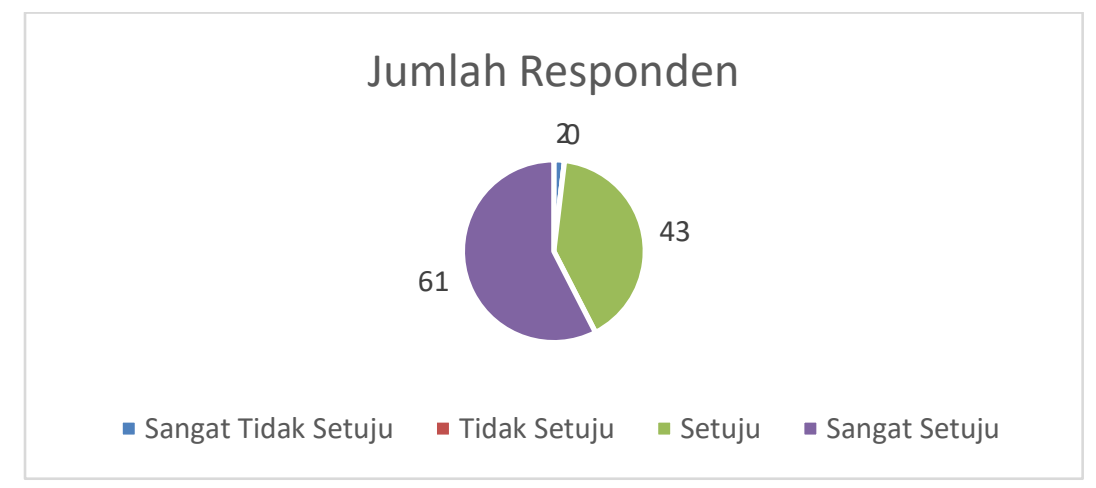

Gambar 10. Tanggapan responden dari pernyataan no. 8 
- Pernyataan no. 9: Video KKN menyadari pentingnya kebersihan Edukasi COVID-19 membuat saya diri agar selalu sehat

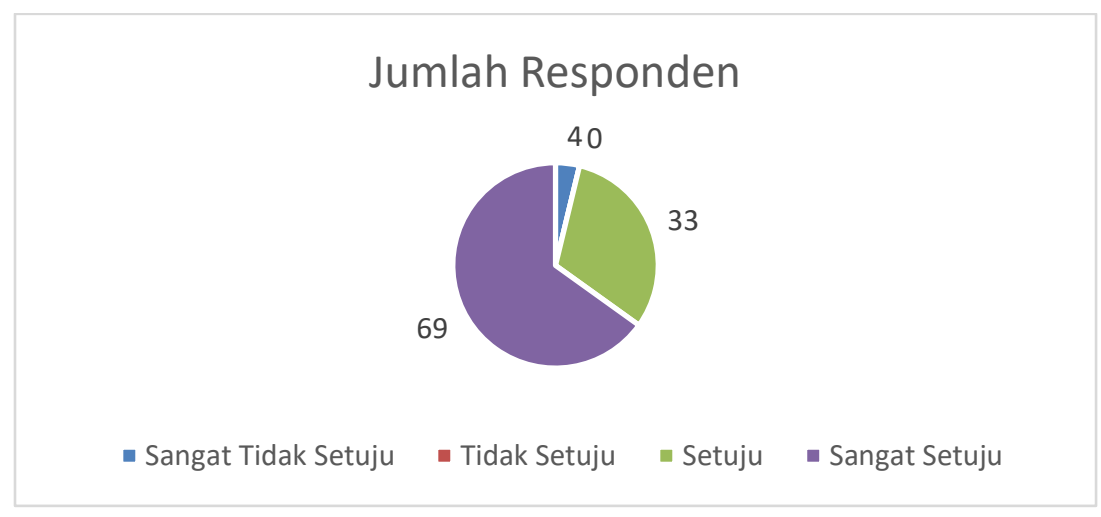

Gambar 11. Tanggapan responden dari pernyataan no. 9

- Pernyataan no. 10: Video KKN peduli terhadap kesehatan diri dari Edukasi COVID-19 membuat saya virus SARS-CoV-2

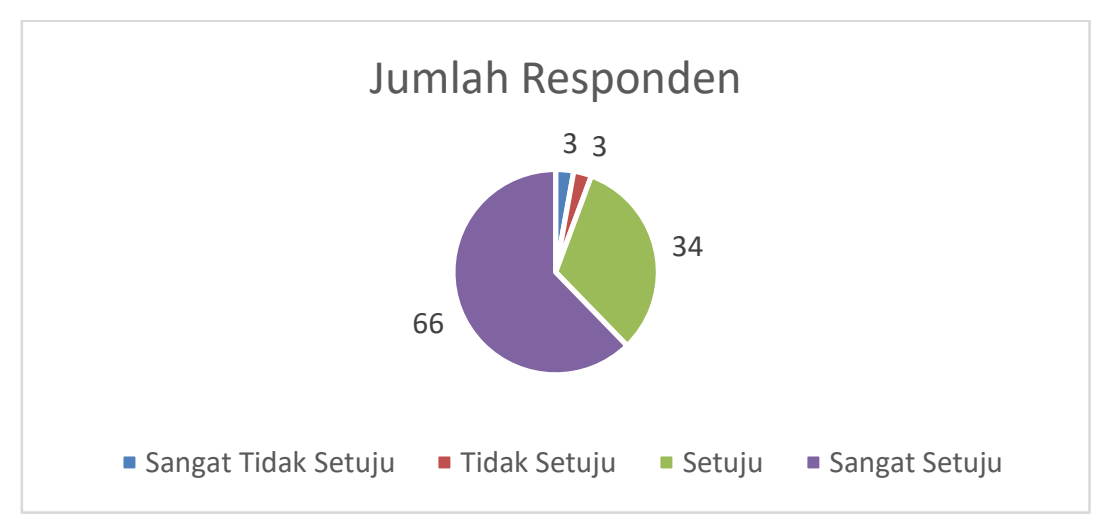

Gambar 12. Tanggapan responden dari pernyataan no. 10

- Pernyataan no. 11: Video KKN Edukasi COVID-19 membuka wawasan baru tentang hand sanitizer dan disinfektan

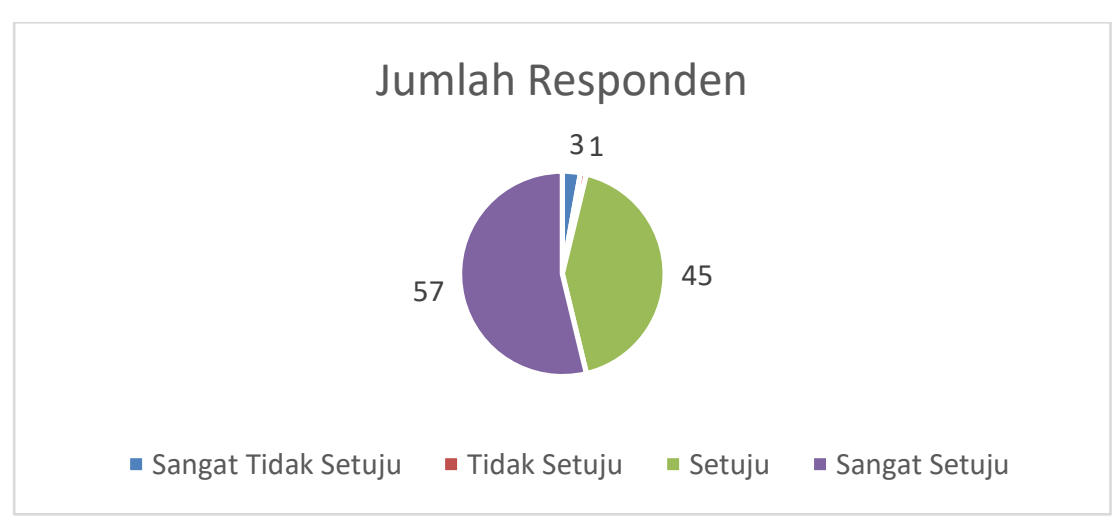

Gambar 13. Tanggapan responden dari pernyataan no. 11 
- Pernyataan no. 12: Video KKN

mengurangi penyebaran hoax Edukasi COVID-19 turut (berita bohong)

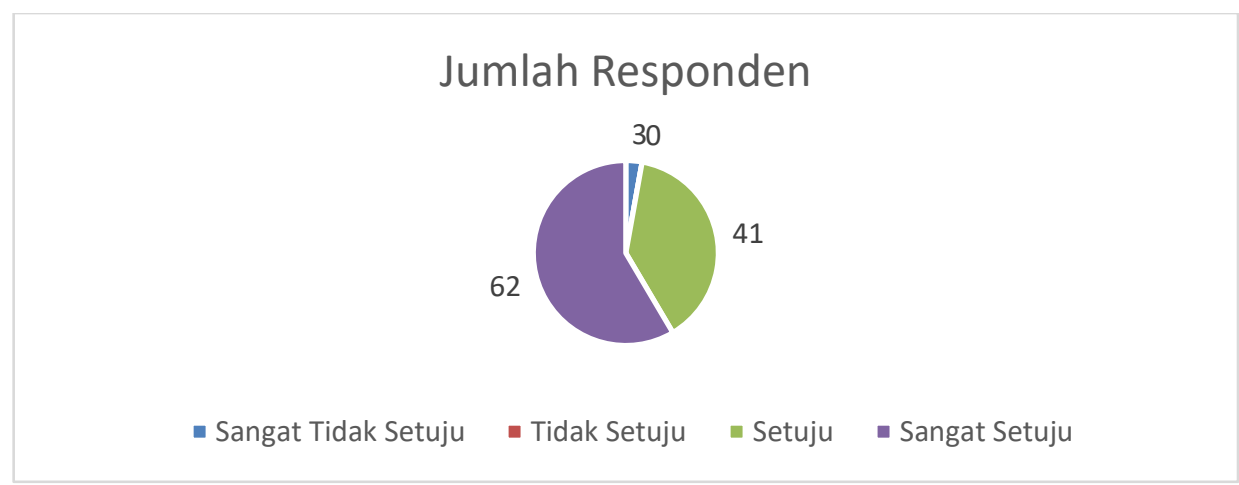

Gambar 14. Tanggapan responden dari pernyataan no. 12

- Pernyataan no. 13: Video KKN

Edukasi COVID-19 menarik dan

mudah dipahami

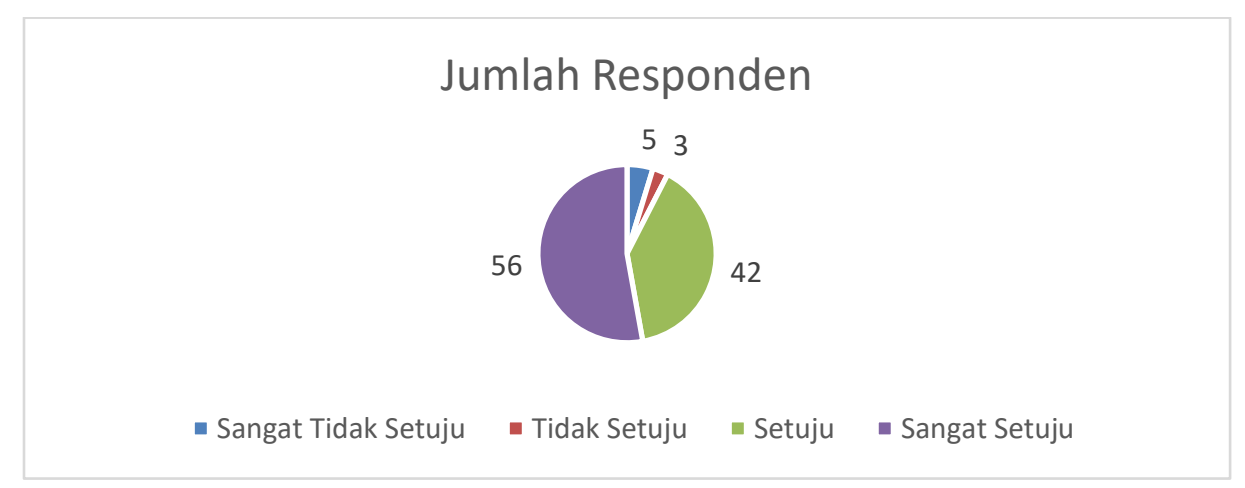

Gambar 15. Tanggapan responden dari pernyataan no. 13

- Pernyataan no. 14: Video KKN

Edukasi COVID-19 bermanfaat

bagi masyarakat

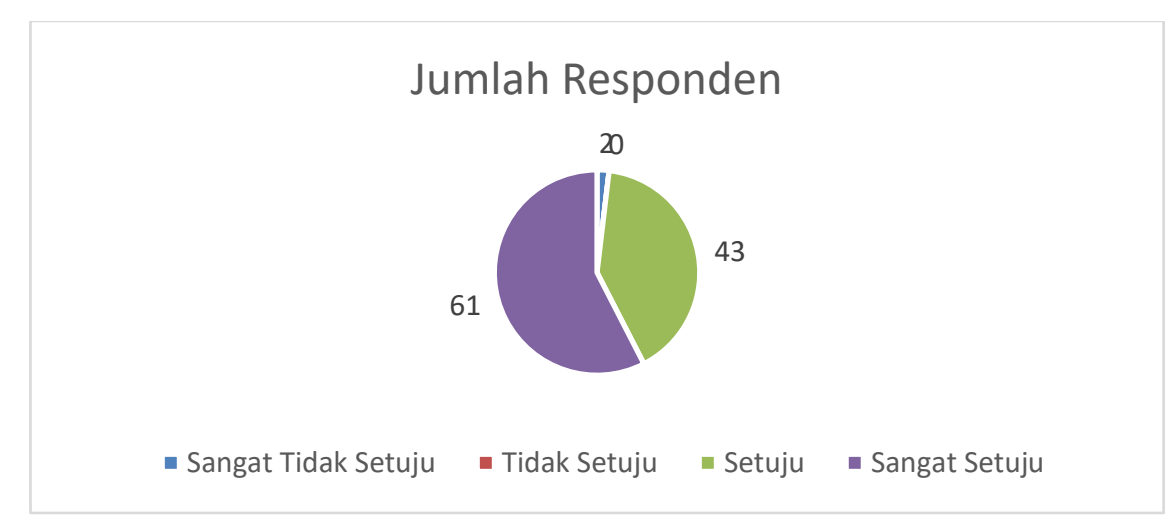

Gambar 16. Tanggapan responden dari pernyataan no. 14

Sarwahita : Jurnal Pengabdian Kepada Masyarakat Vol. 18 No. 1 Tahun 2021| 46 
Dari data tersebut, secara umum responden sudah mendapatkan manfaat dari video KKN, terbukti dari dominannya tanggapan "setuju" dan "sangat setuju" dari beberapa pernyataan yang diajukan. Namun, tetap ada responden yang mengisi angket pada pilihan "tidak setuju" dan "kurang setuju". Hal ini menandakan bahwa perlu adanya kreativitas dan pembawaan materi yang lebih menarik agar video lebih mudah dipahami oleh masyarakat. Jika masyarakat sudah memahami konten video KKN ini, berarti video ini mampu mengedukasi masyarakat mengenai hand sanitizer dan disinfektan yang marak digunakan selama pandemi COVID-19.

Secara umum, masyarakat menanggapi bahwa video ini sudah cukup baik, edukatif, dan bermanfaat sehingga mengurangi penyebaran hoax tentang hand sanitizer dan disinfektan. Selain itu, video edukasi ini menyadarkan masyarakat akan pentingnya kesehatan dan kebersihan diri untuk terhindar dari virus SARSCoV-2. Hadirnya video berkonten edukasi di media sosial Instagram dan YouTube di masa pandemi ini dinilai sangat potensial karena pengguna media sosial dan YouTube yang meningkat selama masa pandemi.

Beberapa materi yang diperoleh masyarakat melalui video KKN Edukasi COVID-19 bertemakan Hand Sanitizer dan Disinfektan, yaitu:

- Hand sanitizer dan disinfektan merupakan bahan kimia yang mengandung senyawa untuk membunuh bakteri atau virus patogen.

- Hand sanitizer digunakan untuk membunuh bakteri atau virus yang berada di permukaan kulit, sedangkan disinfektan digunakan untuk membunuh bakteri atau virus yang berada di permukaan benda mati.

- Bahan aktif yaitu yang terkandung dalam hand sanitizer berupa etanol $80 \%$ atau isopropil alkohol $75 \%$ untuk melarutkan membran lipid dan mendenaturasikan protein pada mikroba (Lee et al., 2020), hidrogen peroksida $1,25 \%$ untuk menonaktifkan spora bakteri yang mengontaminasi larutan, dan gliserol $1,45 \%$ untuk melembabkan kulit (WHO, 2010). Sedangkan disinfektan mengandung bahan aktif yang dapat membunuh bakteri atau virus berupa natrium hipoklorit, hidrogen peroksida, dan chloroxylenol.

- Cara membuat hand sanitizer sesuai pedoman WHO sebanyak $1 \mathrm{~L}$, yaitu: memasukkan alkohol (etanol 96\% sebanyak $833,5 \mathrm{~mL}$ atau isopropil alkohol 99,8\% sebanyak 751,5 mL) ke dalam wadah kemudian dilakukan penambahan hidrogen peroksida $3 \%$ sebanyak $41,7 \mathrm{~mL}$, gliserol $98 \%(14,5 \mathrm{~mL})$, dan air secara berturut-turut, kemudian diaduk dan ditempatkan dalam wadah yang lebih kecil seperti botol. 
Hand sanitizer lebih baik disimpan terlebih dahulu selama 72 jam sebelum digunakan. Penambahan zat lain seperti zat aditif, pewangi, dan pewarna harus diperhatikan (WHO, 2010).

- Cara membuat disinfektan sesuai pedoman WHO, yaitu: mencampur pemutih dan air dengan perbandingan 1:9 untuk menghasilkan disinfektan dengan kandungan klorin sebesar $0,5 \%$, atau mencampur pemutih dan air dengan perbandingan volume 1:99 untuk menghasilkan disinfektan dengan kandungan klorin sebesar 0,05\% (WHO, 2006).

- Pentingnya ketersediaan hand sanitizer dan disinfektan di rumah agar terjaga dari bahaya yang ditimbulkan oleh bakteri atau virus.

- Perlunya kehati-hatian dalam menggunakan hand sanitizer dan disinfektan agar tidak menimbulkan bahaya, sehingga manfaat dari kedua bahan ini akan terasa lebih optimal.

- Dampak yang ditimbulkan jika ada kesalahan dalam menggunakan disinfektan, misalnya menyemprotkan disinfektan ke tubuh manusia, justru dapat menyebabkan iritasi pada kulit dan mata serta masalah pada saluran pernapasan.

\section{PENUTUP}

\subsection{Kesimpulan}

Video KKN Edukasi COVID-19 ini cukup informatif, edukatif, dan bermanfaat sehingga masyarakat mengetahui cara menggunakan hand sanitizer dan disinfektan secara aman dan efektif di masa pandemi. Selain itu, video ini turut mengedukasi masyarakat agar peduli terhadap kesehatan diri sehingga terhindar dari bahaya virus SARS-CoV-2.

\subsection{Saran}

Apabila kondisi memungkinkan di tahun berikutnya, sebagai program lanjutan yang kami sebut dengan istilah "new normal pasca-pandemi", alangkah lebih baik pihak LPPM memberikan izin kepada peserta KKN untuk mengadakan sosialisasi dan penyuluhan langsung kepada masyarakat terkait pembuatan dan penggunaan hand sanitizer serta disinfektan.

\section{DAFTAR PUSTAKA}

APJII. (2020, November). kkn3.pdf. Asosiasi Penyelenggara Jasa Internet Indonesia, 1.

C. Kustandi, D. Darmawan, Pengembangan Media Pembelajaran: Konsep \& Aplikasi Pengembangan Media Pembelajaran bagi Pendidik di Sekolah dan Masyrakat, (Jakarta: Prenada Media, 2020) page 130.

Extension, P. (2011). What is a Disinfectant or Sanitizer? Retrieved December 3, 2020, from PennState Extention website: https://extension.psu.edu/what-isa-disinfectant-or-sanitizer 
Friesland, M., Becker, B., Yang, J., Engelmann, M., Todt, D., Windisch, M. P., ... Pietschmann, T. (2017). Virucidal activity of WHOrecommended formulations against enveloped viruses including Zika, Ebola and emerging Coronaviruses Accepted. 1-18.

Gunter, K. (2020). Potential role of inanimate surfaces for the spread of coronaviruses and their inactivation with disinfectant agents. Infection Prevention in Practice, 2, 10-11. https://doi.org/10.1016/j.infpip.202 0.100044

Lee, J., Jing, J., Yi, T. P., Bose, R. J. C., Mccarthy, J. R., Tharmalingam, N., \& Madheswaran, T. (2020). Hand Sanitizers: A Review on Formulation Aspects, Adverse E ff ects , and Regulations. International Journal of Environmental Research and Public Health, 17, 3326.

Pradhan, D., Biswasroy, P., Kumar, P., Ghosh, G., \& Rath, G. (2020). A Review of Current Interventions for COVID-19 Prevention. Archives of Medical Research. https://doi.org/10.1016/j.arcmed.20 20.04.020

Requiã, R. D., Car, R. L., Hoyer, M., \& Ri, M. (2020). Viruses with different genome types adopt a similar strategy to pack nucleic acids based on positively charged protein domains. Natureresearch, 10(5470), $1-12$. https://doi.org/10.1038/s41598020-62328-w
Rogers, K. (2020). Hand sanitizer. Retrieved from Encyclopædia Britannica website: Encyclopædia Britannica

Sanjua, R. (2018). ScienceDirect Collective properties of viral infectivity' n. Current Opinion in Virology, 33, 1-6. https://doi.org/10.1016/j.coviro.20 18.06.001

Springthorpe, V. S., \& Sattar, S. A. (2009). Chemical disinfection of virus-contaminated surfaces.

Critical Reviews in Environmental Science and Technology, 20(3), 169-229. https://doi.org/10.1080/ 10643389009388396

Wertz, P. W. (2018). Lipids and the Permeability and Antimicrobial Barriers of the Skin. Journal of Lipids, 2018. https://doi.org/https://doi.org/10.11 55/2018/5954034

WHO. (2006). Annex 7. Disinfection. In Collecting, preserving and shipping specimens for the diagnosis of avian influenza A(H5N1) virus infection (pp. 39-41).

WHO. (2010). Guide to Local Production: WHO-recommended Handrub Formulations. In World Health Organization, Geneva (pp. 1-9).

Wieczorek, D., Dobrowolski, A., \& Staszak, K. (2017). Synthesis , Surface and Antimicrobial Activity of Piperidine-Based Sulfobetaines. J Surfact Deterg, 20, 151-158. https://doi.org/10.1007/s11743016-1906-8 